\title{
MEASURING MENTAL HEALTH LITERACY Adaptation and Validation of the Portuguese Version of the Mental Health Literacy Scale (MHLS)
}

(Received: 19 September 2020; accepted: 20 April 2021)

\begin{abstract}
Understanding mental health literacy is essential for promoting empowerment and proactivity in patients, reducing stigma, and increasing population awareness. The constitutive dimensions of mental health literacy are still being researched, and instruments' research can shed light on the involved processes. The Mental Health Literacy Scale (MHLS) is a self-report measure of mental health literacy. This study aimed to adapt the MHLS to Portuguese and evaluate mental health literacy in a broad sample. A broad sample of 337 individuals participated in the adaptation. Besides filling out the MHLS, the participants were invited to fill out a general lifestyle measure. The global results reveal a good internal consistency of the MHLS. A three-factor structure (i.e., attitudes towards mental illness, knowledge about mental illness, and the ability to recognize symptoms) explained $35 \%$ of the total variance. Despite not finding an association with the general lifestyle measure, the MHLS scored higher in women and individuals with higher schooling, as expected. The results reinforce the role of MHLS as a useful measure of mental health literacy. The identified structure is discussed in light of the current understanding and implications of this essential process.
\end{abstract}

Key Words: mental health literacy; MHLS; stigma; mental disorders

\section{Introduction}

There has been a significant evolution in public health concerning the targets and kinds of medical treatments. An aging population means that particular conditions gain prominence. The advances in medicine have reduced infectious diseases and increased the number of treatments for chronic non-communicable diseases. Symptom management and illness prevention interventions play a more significant role.

\footnotetext{
* Corresponding author: Ass. Prof. David Dias Neto, ISPA - Instituto Universitário APPsyCI - Applied Psychology Research Center Capabilities \& Inclusion, Lisboa, Portugal (ORCID ID 0000-0002-3129-262X) Rua Jardim do Tabaco 42, 1100-081; d.neto@campus.ul.pt.
} 
Furthermore, the long duration of treatments implies that they have to become selfmanaged and typically imply a greater complexity and diversity in healthcare. These characteristics mean that citizens need to have an increased and accessible knowledge and they benefit from a proactive attitude toward seeking and managing treatments. Due to this evolution, international organizations such as the World Health Organization (WHO 2013) have been calling for research, intervention, and policy developments in the field of health literacy.

One of the critical domains in health literacy research is mental health. Mental health is not only an issue because of the high prevalence of mental health disorders and their impacts (NeTO \& SiLva 2008; WHO 2018). In Portugal, 22.9\% of adults have met the diagnostic criteria for a mental disorder in the previous year, and these results are similar to other western countries (ALMEIDA \& XAVIER 2013). Another reason for the relevance of addressing mental health is the high rates of stigma (NETO et al. 2017; STUART \& ARBOLEDA-FLÓREZ 2012). The generalization of negative attitudes towards mental illness means that communities will not discuss or convey information on mental health issues. Stigma can, therefore, reduce individual awareness and health-seeking behaviors (GULLIVER et al. 2010).

Despite the existing literature on health literacy in general, research in mental health literacy, in particular, is still in its infancy. There is evidence that programs to increase mental health literacy improve knowledge, awareness, and health-seeking attitudes (Gulliver et al. 2012; Palazzo et al. 2017). Some doubts remain as to which conditions higher health literacy translates into changing behavior. These doubts also remain for other areas of health literacy, such as diabetes (AL SAYAH et al. 2013). This means that future research needs to be conducted to determine which aspects of health literacy and specifically mental health literacy are relevant for behavior change. This increased understanding is essential to promote social inclusion and to empower citizens who have mental health problems.

In mental health literacy, research has also been affected by the lack of researched instruments. Research is frequently conducted with mental health-related instruments or instruments that measure a specific aspect of mental health literacy. In a review of mental health literacy and related measures, WEI and colleagues (2015) found: 69 knowledge measures (14 validated), 111 stigma measures (65 validated), and 35 help-seeking related measures (10 validated). This lack of research as detected in the international literature is higher in Portuguese-speaking countries. To our knowledge, there are no validated instruments in Portuguese. LOUREIRO and colleagues have adapted the 'Survey of Mental Health Literacy in Young People - Interview' (LOUREIRO 2015) for Portuguese, but it is a measure developed for a research survey, and it is specific to adolescents.

The lack of validated instruments also exists in health literacy in general. Two of the reasons for this shortage may be the lack of consensus in the definition of health literacy and the lack of consideration for some of its dimensions in developed measures (HAUn et al. 2014; JORDAN et al. 2011). For example, if health literacy implies reasoning aspects, self-reported measures may be insufficient. These limitations have 
two implications for the present research: Firstly, different instruments may be derived from different understandings of health literacy. Secondly, those who develop instruments must pay great attention to issues of definition and construct.

\section{The Mental Health Literacy Scale}

The concept of mental health literacy assessed in the MHLS (O'CONNOR \& CASEY 2015) was initially designed to measure six attributes grouped into three processes: recognition, knowledge, and attitudes. The six attributes were: 1) Recognition of disorders, 2) Knowledge of how to seek mental health information, 3) Knowledge of risk factors and causes, 4) Knowledge of self-treatments, 5) Knowledge of professional help available, and 6) Attitudes that promote recognition and appropriate selfseeking. An expert panel developed iteratively the items that sought to identify the six dimensions of mental health literacy. After conducting a systematic review of the literature (O'CONNOR et al. 2014), these six attributes were identified. This formulation corresponds to the definition of mental health literacy as considered in the present study.

The authors found a four-factor structure for the final scale, but given the low communalities and mean factor loadings, they concluded that a unifactorial structure was the most meaningful interpretation. The MHLS was found to have good testretest reliability and a Cronbach alpha of .873 (O'CONNOR \& CASEY 2015). The scale also showed promising results when compared with a General Help-seeking Questionnaire, thus showing construct validity. Expanded versions of the scale have been adapted for Mandarin Chinese (CHAO et al. 2020) and Iranian (NEJATIAN et al. 2021).

The scale has been used with UK university students (GORCZYNSKI et al. 2017). The authors found that mental health literacy was higher in women and postgraduate students. Participants with a history of mental problems had lower mental health literacy levels, and the total score was associated with help-seeking behavior. Also, in the UK, the MHLS was used in a large sample of medical students (MARWOOD \& HEARN 2019). The results were similar in showing higher mental health literacy levels in females and students in later years of study. Furthermore, it was higher in participants with a close friend or family member with mental illness.

The present study aims at adapting the MHLS to Portuguese. Considering the lack of measures in Portuguese, this will allow the development of further research on the topic. Also, this measure is one of the most complete measures in assessing this multi-factorial construct. Besides providing a tool for measuring this important concept, improving mental health literacy assessment can increase our understanding of this concept. This understanding is crucial for developing policies or interventions to reduce stigma and empower users. To achieve this goal, we will translate and adapt this scale. The scale's psychometric properties will be analyzed, and a concurrent validity analysis will be conducted with a lifestyle measure. It is assumed that people with high mental health literacy have better lifestyles. The current study aims at tackling the lack of mental health literacy instruments in Portugal. 


\section{Methods}

\subsection{Participants}

Portuguese citizens over 16 years of age were invited to participate in this study. 337 individuals accepted the invitation. 266 (79\%) were female having an average age of 29.2 years $(\mathrm{SD}=10.02$; range $17-72)$. This convenience sample was gathered via a paid ad on social networks. There was an effort to include participants from different regions of the country. The frequencies by district are as follows: Aveiro $4(1.2 \%)$, Beja 3 (0.9\%), Braga 14 (4.2\%), Coimbra 7 (2.1\%), Évora 4 (1.2 \%), Faro 7 (2.1\%), Guarda $2(0.6 \%)$, Leiria $4(1.2 \%)$, Portalegre $3(0.9 \%)$, Porto 21 (6.2\%), Santarém 8 (2.4\%), Lisboa 124 (36.8\%), Setúbal 131 (38.9\%), Vila Real 2 (0.6\%), Viseu 3 $(0.9 \%)$. Table 1 presents the sample's remaining demographic characteristics.

Table 1

Socio-demographic characteristics of the sample

\begin{tabular}{cccc}
\hline Variable & Option & Freq. & Percent. \\
\hline Marital status & Married or cohabiting & 101 & 30 \\
& Divorced or separated & 18 & 5.3 \\
Widow & 1 & 0.3 \\
Professional status & Single & 217 & 64.4 \\
& Full-time & 149 & 44.2 \\
Part-time & 26 & 7.7 \\
Unemployed & 35 & 10.4 \\
Student & 124 & 36.8 \\
& Retired & 3 & 0.9 \\
4 years & 1 & 0.3 \\
6 years & 3 & 0.9 \\
9 years & 13 & 3.9 \\
& 12 years (secondary schooling) & 121 & 35.9 \\
& Bachelor degree or higher & 199 & 59.1 \\
\hline
\end{tabular}

\subsection{Instruments}

Mental Health Literacy Scale (MHLS). The MHLS is a 35-item measure with six different sections. The first section, having eight multiple-choice questions, focuses on the recognition of the most common mental health disorders. The second section, with two multiple-choice questions, explores the knowledge of risk factors and mental illness causes. The third section, possessing two multiple-choice questions, refers to the knowledge of self-treatments; namely, common strategies recommended for 
mental health and wellbeing. The fourth section includes three multiple-choice questions to inquire about the knowledge of available professional help. The fifth section contains four items in a four-point Likert scale to assess knowledge on how to seek mental health information. The final section includes 16 items, in a five-point Likert scale, to measure attitudes that promote recognition and appropriate help-seeking. Twelve items have a reverse scoring. The final score is obtained by summing all the items. The scale results range from 35 to 160 .

'My lifestyle' questionnaire (MLQ). 'My lifestyle' questionnaire (RIBEIRO 2004) comprises 28 items that measure healthy lifestyles in the following dimensions: physical exercise, nutrition, self-care, safety, and drug use. The items are scored on a fivepoint Likert scale ranging from almost always to hardly ever. In the original adaptation, the scale reached a Cronbach alpha of .76 and showed concurrent validity with a general health questionnaire (RIBEIRO 2004). In the current application, this questionnaire reached an alpha of .86 .

\subsection{Procedure and analysis}

The Instituto Piaget review board approved the study. Three Portuguese native speakers independently translated the scale's 35 items. The three translations were discussed and harmonized considering the face and content validity of the items; small cultural adjustments were implemented to make the items understandable to a Portuguese reader. For example, the term 'mental illness' was translated as 'mental disorder' to respect Portuguese usage. A professional translator, not included previously, back-translated all the items into English to ensure that no significant deviations had been made. The original authors were contacted to assist with some of these translation issues.

The following step was the application to a broad community sample. The sample was gathered via social networks, and it was a convenience sample. An initial snowball procedure was complemented with paid Facebook ads to increase the dissemination of the study. A written informed consent was requested to access the questionnaire, and the researcher contacts were provided. Given the size of the application protocol, the participants were invited to fill in the 'My lifestyle' questionnaire a week after filling in the socio-demographic questionnaire and the MHLS. This choice led to a $19 \%$ attrition rate. Both applications were conducted online using google forms.

We conducted an exploratory factor analysis using principal component analysis (PCA) to extract factors to reduce the data into a smaller number of components, calculated as a linear combination of the original variables, to explain as much variance as possible. An oblimin rotation was used (allowing the factors to be correlated), and the selection criteria were eigenvalues greater than 1.1 and factor loadings higher than .5. The analysis was conducted using the Software Statistical Package for the Social Sciences (SPSS - version 25). 


\section{Results}

\subsection{Factor structure of the MHLS}

The original scale's internal consistency of the 35 items was analyzed, and the Cronbach alpha for a single dimension was .853. The average score for the whole sample was $129.1(\mathrm{SD}=12.4)$, range $35-160$. One of the present study's goals was to investigate the factor structure of the MHLS and determine which of the items best represent each of the dimensions. This analysis included all of the 35 items of the scale and was conducted on the data collected from the 337 individuals. The factor solution produced seven factors with eigenvalues greater than 1.1, but only one factor explained more than $10 \%$ of the variance.

The original authors of the MHLS had developed the measure to assess a threedimension formulation of mental health literacy (O'CONNOR et al. 2014). Considering this formulation, the scales' 35 items were entered into the PCA using a forced factor extraction of 3 factors, in which eigenvalues greater than 1.1 and factor loadings equal or higher than .5 were interpreted to represent a particular factor. This analysis produced a solution that together accounted for $35 \%$ of the variance.

Considering the dimensions proposed in the literature, these factors were labelled: (1) Attitudes towards mental illness (items: 29, 30, 31, 32, 33, 34, 35); (2) Knowledge about mental illness (items: 16, 17, 18, 19, 20, 21, 24, 28); and (3) Ability to recognize symptoms (items: 1, 4, 5, 6, 8). All the subscales demonstrated fairly good internal reliability, ranging from 0.66 to 0.89 , and the content of these loadings is shown in Table 2.

Table 2

Pattern matrix of the MHLS $(n=337)$

\begin{tabular}{|c|c|c|c|}
\hline & FI & $F 2$ & $F 3$ \\
\hline Alpha: & $\alpha=.89$ & $\alpha=.66$ & $\alpha=.68$ \\
\hline Explained variance: & $18 \%$ & $9 \%$ & $8 \%$ \\
\hline 31. How willing would you be to make friends with someone with a mental illness? & .796 & & \\
\hline 30. How willing would you be to spend an evening socializing with someone with a mental illness? & .782 & & \\
\hline 33. How willing would you be to have someone with a mental illness marrying into your family? & .773 & & \\
\hline 32. How willing would you be to have someone with a mental illness start working closely with you on a job? & .766 & & \\
\hline 35. How willing would you be to employ someone if you knew they had a mental illness? & .738 & & \\
\hline 29. How willing would you be to move next door to someone with a mental illness? & .724 & & \\
\hline 34. How willing would you be to vote for a politician if you knew they had suffered a mental illness? & .621 & & \\
\hline 6. Knowledge on agoraphobia & & .616 & \\
\hline 1. Knowledge on social phobia & & .586 & \\
\hline 5. Knowledge on dysthymia & & .578 & \\
\hline
\end{tabular}




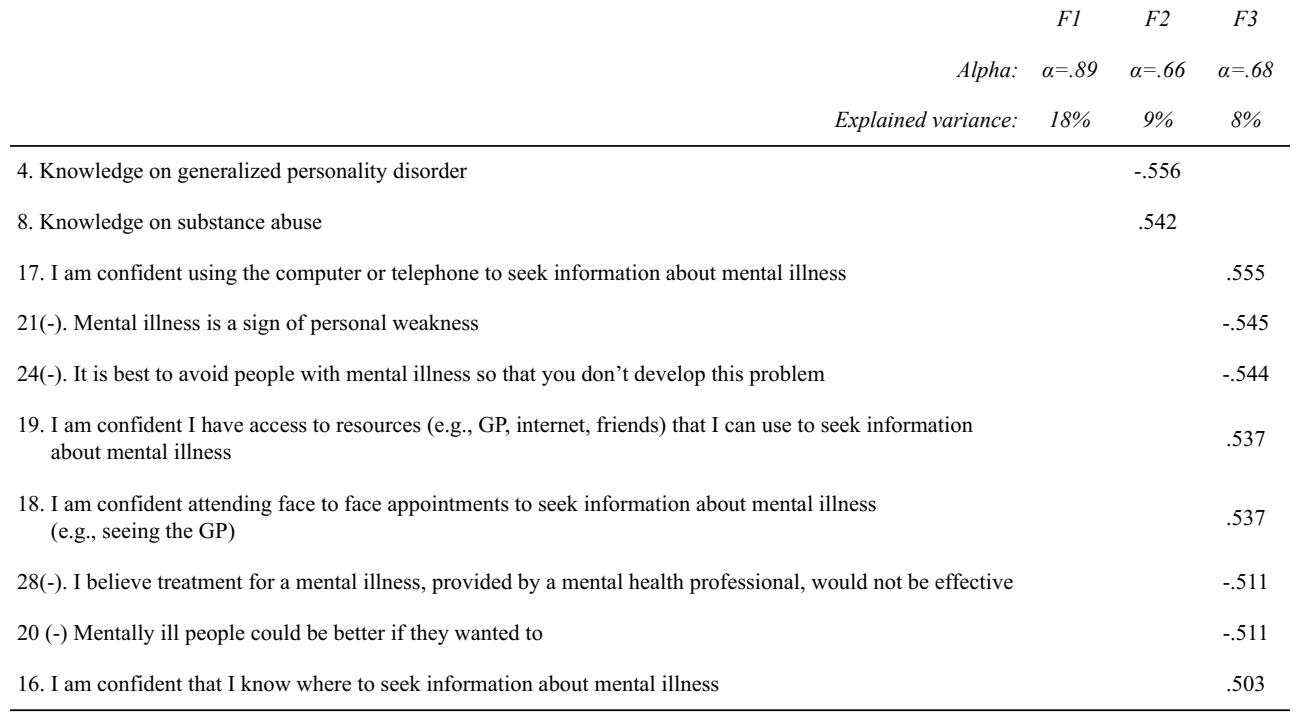

F1 - Attitudes towards mental illness; F2 - Ability to recognize symptoms; F3 - Knowledge about mental illness. Items that scored below the threshold $(<.5)$ for the three factors are omitted from this table.

As presented in Table 3, these factors significantly correlate with each other and the total score. A moderate correlation was found between 'Attitudes towards MH' and 'Knowledge about MH'. 'Symptom recognition' weakly correlates with a 'Knowledge about MH' and very weakly with 'Attitudes towards MH'.

Table 3

Pearson correlations between factors and the total score $(\mathrm{N}=337)$

\begin{tabular}{cccc}
\hline & Attitudes towards MH & Knowledge about MH & Symptom recognition \\
\hline Attitudes towards $M H$ & 1 & & \\
Knowledge about $M H$ & $.40^{* *}$ & 1 & 1 \\
Symptom recognition & $.12^{*}$ & $.29^{* *}$ & $.53^{* *}$ \\
Total Score & $.73^{* *}$ & $.77^{* *}$ & \\
\hline
\end{tabular}

${ }^{*} \mathrm{p}<.05$ (two tailed) ${ }^{* *} \mathrm{p}<.001$ (two tailed).

\subsection{Descriptive and validity analysis}

The validity of the test was assessed by contrasting it with an existing lifestyle questionnaire and conducting a comparative analysis using the sample's main demographic characteristics. The global score of the MHLS was compared against the 'My 
Lifestyle' questionnaire (MLQ) results. No correlation was found between the two measures, $\mathrm{r}(273)=.06, \mathrm{p}=.364$.

A comparative analysis was carried out for the proposed factors and total score of the MHLS, according to sex, level of education, and age group (See Table 4). A ttest analysis indicated a significant difference between males and females, with females having higher total scores $(\mathrm{t}(335)=5.3 ; \mathrm{p}=.000)$ and concerning 'Attitudes towards $\mathrm{MH}$ ' $(\mathrm{t}(335)=5.1 ; \mathrm{p}=.000)$ and 'Knowledge about $\mathrm{MH}$ ' $(\mathrm{t}(335)=3.6 ; \mathrm{p}$ $=.000)$. Age was recoded in three levels: $17-30,31-44$, and 45-72. There were no significant differences by age group concerning the proposed factors and the total score of the MHLS.

Education level was recoded into two groups: from primary to secondary level and university graduation. Significant differences existed between these two levels of education (See Table 4). Participants with higher levels of education have higher scores on MHLS ( $\mathrm{t}(335)=-5.23 ; \mathrm{p}=.000)$. This was also observed for the three factors: 'Attitudes towards MH' ( $\mathrm{t}(335)=-2.33 ; \mathrm{p}=.020)$; 'Knowledge about $\mathrm{MH}$ ' $(\mathrm{t}(335)=-4,45 ; \mathrm{p}=.000)$; and 'Symptom recognition' $(\mathrm{t}(335)=-4.47 ; \mathrm{p}=.000)$.

Table 4

Descriptive statistics and demographic characterization of MHLS's three factors

\begin{tabular}{|c|c|c|c|c|}
\hline & $\begin{array}{l}\text { Attitudes towards } M H \\
\quad(\text { Min } 1 ; \text { Max 5) }\end{array}$ & $\begin{array}{l}\text { Knowledge about MH } \\
\text { (Min 2.6; Max 5) }\end{array}$ & $\begin{array}{l}\text { Symptom Recognition } \\
\text { (Min 1; Max 4) }\end{array}$ & $\begin{array}{c}\text { Total score } \\
\text { (Min 93; Max 155) }\end{array}$ \\
\hline Total & $\mathrm{M}=3.88(\mathrm{SD}=.76)$ & $\mathrm{M}=4.14(\mathrm{SD}=.55)$ & $\mathrm{M}=3.20(\mathrm{SD}=.49)$ & $\mathrm{M}=129.11(\mathrm{SD}=12.44)$ \\
\hline \multicolumn{5}{|l|}{$\operatorname{Sex}$} \\
\hline Male & $\mathrm{M}=3.48(\mathrm{SD}=.88)$ & $\mathrm{M}=3.93(\mathrm{SD}=.58)$ & $\mathrm{M}=3.14(\mathrm{SD}=.47)$ & $\mathrm{M}=122.4(\mathrm{SD}=13.1)$ \\
\hline Female & $\mathrm{M}=3.98(\mathrm{SD}=.69)$ & $\mathrm{M}=4.19(\mathrm{SD}=.52)$ & $\mathrm{M}=3.21(\mathrm{SD}=.49)$ & $\mathrm{M}=130.9(\mathrm{SD}=11.6)$ \\
\hline \multicolumn{5}{|l|}{ Education } \\
\hline Prim. - sec. & $\mathrm{M}=3.76(\mathrm{SD}=.80)$ & $\mathrm{M}=3.98(\mathrm{SD}=.51)$ & $\mathrm{M}=3.06(\mathrm{SD}=.46)$ & $\mathrm{M}=125.0(\mathrm{SD}=11.6)$ \\
\hline University & $\mathrm{M}=3.95(\mathrm{SD}=.72)$ & $\mathrm{M}=4.25(\mathrm{SD}=.54)$ & $\mathrm{M}=3.29(\mathrm{SD}=.48)$ & $\mathrm{M}=131.9(\mathrm{SD}=12.2)$ \\
\hline \multicolumn{5}{|l|}{ Age groups } \\
\hline $17-30$ & $\mathrm{M}=3.88(\mathrm{SD}=.71)$ & $\mathrm{M}=4.08(\mathrm{SD}=.53)$ & $\mathrm{M}=3.17(\mathrm{SD}=.47)$ & $\mathrm{M}=128.6(\mathrm{SD}=11.9)$ \\
\hline $31-44$ & $\mathrm{M}=3.94(\mathrm{SD}=.80)$ & $\mathrm{M}=4.30(\mathrm{SD}=.56)$ & $\mathrm{M}=3.25(\mathrm{SD}=.50)$ & $\mathrm{M}=131.4(\mathrm{SD}=13.0)$ \\
\hline+45 & $\mathrm{M}=3.58(\mathrm{SD}=.89)$ & $\mathrm{M}=4.07(\mathrm{SD}=.50)$ & $\mathrm{M}=3.21(\mathrm{SD}=.52)$ & $\mathrm{M}=125.4(\mathrm{SD}=13.4)$ \\
\hline
\end{tabular}

\section{Discussion}

The present study sought to develop the Portuguese version of the Mental Health Literacy Scale (MHLS). This adaptation was conducted to respond to a lack of validated instruments for mental health literacy, in general, and in Portuguese-speaking countries in particular. The overall results suggest that the Portuguese version of the 
MHLS has good psychometric properties. The scale has good internal consistency showing that the items reliably represent the same construct.

As the original authors stated, no reliable factor structure was found in the preliminary unrestrained exploratory factor analysis in the present study. The original authors found that a unifactorial structure, for mental health literacy, explained their application of the MHLS. Unlike the original study, we obtained a valid structure when forced for three factors. The reason for this option was the theoretical consideration of three broad constitutive elements for mental health: relevant knowledge about mental health, attitudes towards mental illness, and recognition competencies. It is important to notice that this factorial structure merely explains $35 \%$ and that the alphas for the 'Symptom recognition' and 'Knowledge about MH' factors only approximately reach the acceptable values. Nevertheless, the results give strength to thinking about mental health literacy as the conjugation of the knowledge that individuals have about mental health and the attitudinal dimension of this knowledge as well as the application to processes such as self-recognition of signs and symptoms of distress. It is important to keep in mind that in self-reported health literacy measures, other processes or reasoning dimensions may be more difficult to assess.

The results of our population's characterizations are similar to those found in the literature. Women and individuals with higher schooling show greater health literacy. Concerning the contrast with a lifestyle questionnaire, no significant association was found with our measure. This may have happened for several reasons. Firstly, the chosen instrument was not specific to mental health. It may be that mental health literacy does not relate as well with general lifestyle measures. Secondly, the fact that not all participants filled out the lifestyle questionnaire may have skewed the results. The original study had found significant associations with a General Helpseeking Questionnaire but not with a psychological distress measurement (O'CONNOR $\&$ CASEY 2015). So, research is needed to evaluate which variables are functionally related to mental health literacy.

This study has several limitations. The size of the sample is small given the number of items of the scale (participant to item ratio is 9.6). The fact that the data was gathered online means that participants may be more literate than the general population. Furthermore, the sample was imbalanced with respect to gender $(79 \%$ female). This may have affected the scale's overall results with a higher prevalence of health literacy scores. Our concurrent validity results suggest that future research needs to assess the correlation between this scale and other outcomes. Finally, there may be elements on the original scale that, despite our concern for cultural adaptation, may have a different meaning than in its original context. For example, CBT is much less familiar with Portuguese-speaking individuals than in countries from the Anglo-Saxon world. Items that involve understanding such elements may be interpreted differently in different cultures. We chose a conservative stance and kept the scale as close to the original as possible. Future research should further investigate the cultural differences in this or other instruments. 
Researching mental health literacy is essential for several reasons. The understanding of mental health literacy may help to reduce societal stigma and its impact on help-seeking behavior. This understanding is also paramount in developing individual and public health interventions to improve mental health literacy. Mentalhealth literate individuals will be able to recognize and act upon signs of distress. This proactivity is essential in addressing the significant impacts of mental health problems and providing care, as well as promoting the inclusion of these individuals.

\section{References}

Al Sayah, F., S.R. Majumdar, B. Williams, S. Robertson \& J.A. Johnson (2013) 'Health Literacy and Health Outcomes in Diabetes: A Systematic Review', Journal of General Internal Medicine 28(3), 444-52 (https://doi.org/10.1007/s11606-012-2241-z).

Almeida, J. \& M. XAVIER (2013) Estudo epidemiológico nacional de saúde mental: $1^{\circ}$ relatório (Lisboa: Nova Medical School) retrieved 4 May 2021 from http://www.fcm.unl.pt/main/ alldoc/galeria_imagens/Relatorio_Estudo_Saude-Mental_2.pdf.

CHAO, H.J., Y.J. LIEN, Y.C. KAO, I.C. TÁSI, H.S. LIN \& Y.Y. LIEN (2020) 'Mental Health Literacy in Healthcare Students: An Expansion of the Mental Health Literacy Scale', International Journal of Environmental Research and Public Health 17(3), 948 (https://doi.org/10.3390/ ijerph17030948).

Gorczynski, P., W. Sims-schouten, D. Hill \& J.C. WiLson (2017) 'Examining Mental Health Literacy, Help Seeking Behaviours, and Mental Health Outcomes In UK University Students', The Journal of Mental Health Training, Education and Practice 12(2), 111-20 (https://doi.org/10.1108/JMHTEP-05-2016-0027).

Gulliver, A., K.M. Griffiths \& H. Christensen (2010) 'Perceived Barriers and Facilitators to Mental Health Help-Seeking in Young People: A Systematic Review’, BioMed Central Psychiatry 10, 113 (https://doi.org/10.1186/1471-244X-10-113).

Gulliver, A., K.M. Griffiths, H. Christensen \& J.L. Brewer (2012) 'A Systematic Review of Help-Seeking Interventions for Depression, Anxiety and General Psychological Distress', BMC Psychiatry 12, 81 (https://doi.org/10.1186/1471-244X-12-81).

Haun, J.N., M.A. Valerio, L.A. McCormack, K. Sørensen \& M.K. PaAsche-Orlow (2014) 'Health Literacy Measurement: An Inventory and Descriptive Summary of 51 Instruments', Journal of Health Communication 19(2), 302-33. (https://doi.org/10.1080/10810730. 2014.936571).

Jordan, J.E., R.H. Osborne \& R. Buchbinder (2011) 'Critical Appraisal of Health Literacy Indices Revealed Variable Underlying Constructs, Narrow Content and Psychometric Weaknesses', Journal of Clinical Epidemiology 64(4), 366-79 (https://doi.org/10.1016/j.jclinepi. 2010.04.005).

LoureIro, L.M.J. (2015) 'Questionnaire for Assessment of Mental Health Literacy - QuALiSMental: Study of Psychometric Properties', Revista de Enfermagem Referencia, 4(4), 79-88 (https://dx.doi.org/10.12707/RIV14031).

Marwood, M.R. \& J.H. HEARn (2019) 'Evaluating Mental Health Literacy in Medical Students in the United Kingdom', The Journal of Mental Health Training, Education and Practice 14(5), 339-47 (https://doi.org/10.1108/JMHTEP-01-2019-0001).

Nejatian, M., H. Tehrani, V. Momeniyan \& A. Jafari (2021) 'A Modified Version of the Mental Health Literacy Scale (MHLS) in Iranian People', BMC Psychiatry 21, 53 (https://doi.org/ 10.1186/s12888-021-03050-3). 
Neto, D.D. \& A.N. Silva (2008) 'Characterization of Readmissions at a Portuguese Psychiatric Hospital: An Analysis Over a 21 Month Period', The European Journal of Psychiatry 22(2), 69-76 (https://doi.org/10.4321/s0213-61632008000200002).

Neto, D.D., M.J. Figueiras, S. Campos \& P. Tavares (2017) 'Impact of Economic Crisis on the Social Representation of Mental Health: Analysis of a Decade of Newspaper Coverage', International Journal of Social Psychiatry 63(8), 736-43 (https://doi.org/10.1177/ 0020764017737102).

O'Connor, M. \& L. CASEY (2015) 'The Mental Health Literacy Scale (MHLS): A New ScaleBased Measure of Mental Health Literacy', Psychiatry Research 229(1-2), 511-16 (https://doi.org/10.1016/j.psychres.2015.05.064).

O'ConNor, M., L. CASEY \& B. Clough (2014) 'Measuring Mental Health Literacy - A Review of Scale-Based Measures', Journal of Mental Health, 23(4), 197-204 (https://doi.org/10.3109/ 09638237.2014.910646).

Palazzo, M.C., B. Dell'Osso, A.C. Altamura, D.J. Stein \& D.S. Baldwin (2014) 'Health Literacy and the Pharmacological Treatment of Anxiety Disorders: A Systematic Review', Human Psychopharmacology 29(3), 211-15 (https://doi.org/10.1002/hup.2397).

RiBEIRO, J.L.P. (2004) 'Avaliação das intenções comportamentais relacionadas com a promoção e protecção da saúde e com a prevenção das doenças', Análise Psicológica 2(22), 387-97.

Stuart, H. \& J. Arboleda-Flórez (2012) 'A Public Health Perspective on the Stigmatization of Mental Illnesses', Public Health Reviews 34, 12 (https://doi.org/10.1007/BF03391680).

Wei, Y., P.J. McGrath, J. HaYden \& S. Kutcher (2015) 'Mental Health Literacy Measures Evaluating Knowledge, Attitudes and Help-Seeking: A Scoping Review', BMC Psychiatry 15, 291 (https://doi.org/10.1186/s12888-015-0681-9).

World Health Organization (2013) Health Literacy: The Solid Facts, retrieved 1 May 2021 from https://apps.who.int/iris/bitstream/handle/10665/128703/e96854.pdf.

World Health Organization (2018) Mental Health Atlas - 2017, retrieved 1 May 2021 from http://apps.who.int/iris/bitstream/handle/10665/272735/9789241514019-eng.pdf?ua=1. 


\section{APPENDIX \\ MHLS - Item translation}

\section{Recognition of disorders}

01) Se alguém ficou extremamente nervoso ou ansioso em uma ou mais situações com outras pessoas (ex. numa festa) ou em situações de desempenho (ex. falar numa reunião) em que pessoas como esta tinham medo de ser avaliados por outros e que agiriam de forma que era humilhante ou sentindo-se embaraçados, então em que medida considera provável que pessoas como esta tenham Fobia Social.

02) Se alguém ficou muito preocupado com um determinado número de eventos ou atividades onde este nível de preocupação despropositada, teve dificuldade em controlar esta preocupação e teve sintomas físicos, como tensão muscular e fadiga, então em que medida considera provável acha que pessoas como esta têm Perturbação de Ansiedade Generalizada.

03) Se alguém experienciou um humor negativo por duas ou mais semanas, teve perda de prazer ou interesse nas suas actividades normais e experimentou mudanças no seu apetite e sono, então em que medida considera provável que pessoas como esta têm uma Perturbação Depressiva Major.

04) Em que medida considera provável que Perturbações da Personalidade é uma categoria de perturbação mental

05) Em que medida considera provável que Distimia é uma perturbação mental.

06) Em que medida considera provável que o diagnóstico de Agorafobia inclua ansiedade sobre situações em que a fuga possa ser difícil ou embaraçosa

07) Em que medida considera provável que o diagnóstico de Perturbação Bipolar inclua períodos de humor elevado (ou seja, em alta) e períodos de humor deprimido (ou seja, em baixo).

08) Em que medida considera provável que o diagnóstico de Dependência de Substâncias inclua tolerância física e psicológica (ou seja, que é preciso maior quantidade de droga para ter o mesmo efeito).

\section{Knowledge of risk factors and causes}

09) Em que medida considera provável que no geral, em Portugal, as mulheres têm MAIOR probabilidade de experienciar uma perturbação de qualquer tipo quando comparadas com os homens.

10) Em que medida considera provável que, no geral, em Portugal, os homens têm MAIOR probabilidade de experienciar uma perturbação da ansiedade quando comparados com as mulheres 


\section{Knowledge of self-treatments}

11) Em que medida considera que seria útil para alguém melhorar a qualidade do sono, havendo dificuldades em gerir as suas emoções (ex., ficando muito ansiosos ou deprimidos)

12) Em que medida considera que seria útil para alguém evitar todas as actividades ou situações que fazem sentir ansiedade, em caso de existirem dificuldades em gerir as emoções.

\section{Knowledge of available professional help}

13) Em que medida considera que é provável que a Terapia Cognitivo-Comportamental (TCC) é uma terapia que se baseia em desafiar os pensamentos negativos e a aumentar os comportamentos positivos.

14) Os profissionais de saúde mental estão sujeitos à confidencialidade, no entanto, existem certas condições nas quais isto não se aplica. Em que medida é que considera provável que a seguinte circunstância permitiria que um profissional de saúde mental quebrasse a confidencialidade:

\section{Se você está em risco eminente de magoar-se a si ou aos outros}

15) Os profissionais de saúde mental estão sujeitos à confidencialidade; no entanto, existem certas circunstâncias nas quais isto não se aplica. Em que medida é que considera provável que a seguinte circunstância permitiria que um profissional de saúde mental quebrasse a confidencialidade: Se o seu problema não ameaça a sua vida e os profissionais querem ajudar outros a apoiarem-no.

\section{Knowledge of how to seek mental health information}

16) Estou confiante de que sei onde procurar informações sobre perturbação mental

17) Estou confiante que sei usar o computador ou telefone para procurar informação sobre perturbação mental.

18) Estou confiante que consigo fazer contactos pessoais para procurar informação sobre perturbação mental (ex., com o médico de família)

19) Estou confiante que tenho acesso a recursos (ex., medico de família, internet, amigos) para procurar informação sobre perturbação mental

\section{Attitudes that promote recognition and appropriate self-seeking}

20) Pessoas com perturbação mental poderiam "dar a voltar por cima" se quisessem

21) A perturbação mental é um sinal de fraqueza pessoal

22) Perturbação mental não é uma doença médica real

23) Pessoas com perturbação mental são perigosas 
24) É melhor evitar pessoas com perturbação mental de forma a não desenvolver este problema

25) Se eu tivesse uma perturbação mental, não contaria a ninguém

26) Consultar um profissional de saúde mental significa que não se é forte o suficiente para gerir as próprias dificuldades

27) Se eu tivesse uma perturbação mental, não procurava ajuda de um profissional de saúde mental

28) Eu acredito que o tratamento para a perturbação mental, prestado por um profissional de saúde mental, não seria eficaz

29) Estaria disponível para mudar para a casa ao lado de alguém com perturbação mental?

30) Estaria disponível para passar uma tarde a socializar com alguém com uma perturbação mental?

31) Estaria disponível para ser amigo de alguém com uma perturbação mental?

32) Estaria disponível para ter alguém com perturbação mental a trabalhar junto de si?

33) Estaria disponível para ter alguém com perturbação mental casada com um familiar seu?

34) Estaria disponível para votar num político que soubesse que tinha sofrido de uma perturbação mental?

35) Estaria disponível para empregar alguém se soubesse que tinha tido uma perturbação mental? 